3. Danylenko G. M., Golubnycha G. I. Features of physical development of children of primary school age during adaptation to educational activity. Ukrayinskyj zhurnal dytyachoyi endokrynologiyi. 2019. N 2. S. 39-44 (in Ukrainian).

4. Criteria for assessing the physical development of school-age children: approved by the order of the Health Ministry of Ukraine dated 13.09.2013 N 802 (in Ukrainian) : http://zakon5.rada.gov.ua/laws/show/z 1694-13.

5. Kaminska T. M. Retrospective studies of physical development of schoolchildren. Neonatologiya, hirurgiya ta perynatalna medycyna. 2015. Vol. V, N 2(16). P. 44-50 (in Ukrainian).

6. Senatorova G. S., Chajchenko T. V., Onikiyenko O. L., Sanina I. O. Cymbal V. M. Physical development and anthropometric parameters of adolescents in the Kharkiv region. Likarska sprava. 2012. N 1-2. P. 95-101 (in Ukrainian).

7. Velychko V.I., Babij I.L. Physical development of school-age children in the South of Ukraine. Zdorovye rebenka. 2011. N 3. P. 30 (in Ukrainian).

DOI https://doi.org/10.30525/978-9934-588-81-5-2.54

\title{
ADAPTATION OF CHILDREN OF PRIMARY SCHOOL AGE TO THE DENTAL VISIT
}

\author{
Onyshchenko A. V. \\ PhD Student at the Department of Pediatric Dentistry \\ Ukrainian Medical Stomatological Academy \\ Sheshukova O. V. \\ $P h D$ in Medicine, Professor, \\ Head of the Department of Pediatric Dentistry \\ Ukrainian Medical Stomatological Academy \\ Poltava, Ukraine
}

Why would a dentist use behaviour guidance with a child? The main goals of behaviour guidance are:

1. Establish communication.

2. Alleviate fear and anxiety

3. Deliver quality dental care 200

4. Build a trusting relationship between dentist and child 
5. Promote the child's positive attitude toward oral/dental health and oral health care

Since every child is different, dentists have a wide range of approaches to help a child complete needed dental treatment. A dentist makes a recommendation of behaviour guidance methods for the child based upon her health history, special health care needs, dental needs, type of treatment required, the consequences of no treatment, her emotional and intellectual development, and parental preferences [1, 705].

There are two main reasons why a dentist utilises behaviour guidance techniques for the child.

- The first reason is anxiety. Children typically respond to an unfamiliar dental office in the same way they respond to a new paediatrician, new childcare provider, or first visit to someone's home. Some are totally comfortable; others are fearful in the new or unfamiliar situation.

- The second reason is pain. If a child's first visit to a dentist is an emergency situation, perhaps because of a toothache or mouth injury, she is far more likely to be unhappy during the visit. This is why the most important behaviour guidance technique is early and regular dental visits. If a child visits a dentist when her mouth is comfortable, she is much more likely to find the visit pleasant and fun.

Parents play an important role in their child's safety during dental treatment. In particular, stay up-to-date on the child's health status. Be certain to inform the dentist about changes in the child's medical history, including any illnesses and any medications, both prescription and overthe-counter $[2,121]$.

A well-informed parent should know the choices available to relieve the anxiety or discomfort of the child during dental treatment. Working together, a parent and the dentist can select the best treatment methods to make the child's visit as safe and comfortable as possible.

Younger school age is important in the formation of the personality of the child, because that's when the Foundation is laid for personal development of students in primary school [3, 256].

Age of children 1-4 classes can be considered: minor social and moral experience, heightened emotionality, impressionability and at the same time, the plasticity of ethical stress, impulsivity, and the immediacy of the child's behavior, willingness to expand the circle communication. Therefore, the coordination behavior and awareness of the moral phenomena life is characterized by emotional generalizations, analyze situations and actions that conform to universal moral values. The gap between knowledge of moral principles and appropriate behavior - characteristic the property is 
a child of this age. Future development will be to acquire such moral feelings: guilt, shame, duty, responsibility, justice, dignity, conscience.

The basic needs of the child in the primary grades is a necessity in the dealing with people in emotional contact, recognition, evaluation of their actions and deeds, identifying its own position relative to others, the world, in friendship, sociability, respect for personality, self-esteem, the acquisition of new knowledge and skills for understanding the environment.

Before a teacher becomes an important task: to select the motive of the act, explaining to the child his nature and correctness in a variety of typical life situations giving her the emotional «experience» along with practical application of knowledge.

Participating in joint activities, students learn to build their relationships with peers, enter into a collective of peers. They have the need for vzaimopomosch and mutual assistance $[4,11]$.

At this age stage, the child forms the core of personality (moral feelings, values, beliefs), the acquisition of experience moral conduct. She learns not only to comply with the requirements of the team, and and takes an active part in the formulation of requirements, choice of assignments, things that to her soul. Trainees get another tumor - a relatively stable form behavior and activities that will form the basis for the formation of her character.

After the first class in some children not fully formed personal phenomenon, characteristic of preschool children, namely:

- lack of awareness of the perception of school life, the need to organize and arrange it according to certain laws and regulations cohabitation;

- lack of awareness of internal ethical instances, such as conscience (orientation only on external control from adults, inability to act yourself) that causes students a feeling of insecurity, causing conflicts in communication;

- lack of benefits and thoughtful over impulsive action (deterrence desires occurs only if the expectation of reward or punishment);

- aborted self-esteem.

The teacher in the second grade should continue educational work, aimed at correcting these deficiencies with the aim of building specific to younger students personality tumors: the arbitrariness of mental processes, internal action plan and reflection, intellectualization of the child's life.

In children's actions at the end of the second year of training has seen position in relation to what surrounds them. Growing and changing internal ethical instances formed the moral motives of behavior; develop the ability to empathize, to sympathize, and hence to cooperate with adults and peers. 
Primary school age (I. D. Beham) is favorable the education of the child is fundamental to his moral development tumors, which is the ability to appreciate the personality of the person $[5,36]$.

The main neoplasm of educational activity is the formation of theoretical thinking of the child, which finds an expression in the level formation of children's personality, fundamentals many moral concepts: kindness (humanity), humanity, mercy, sensitivity, compassion, honesty, justice, patience, etc.

The formation of personality of Junior schoolboy is largely is determined by the implementation in the educational process of the activity approach, according to which moral rules and norms the child learns actively, in the process activities and communication with adults, peers, older and younger children.

The main function of it is that it experience the attitude the child to the world, to people, to myself.

The effectiveness of different types of education depends on the orientation educational process, forms and methods of organization. Priority for students the initial class of active methods, aimed at independent search the truth and contribute to the formation of critical thinking, initiative and creativity.

Because at a younger age in children is dominated by creative thinking, the the most characteristic are the following forms of activity: role-play, role-playing game, the game-dramatization, dramatization, the gameconversation, grabandrun, tour, games, exercise, creative panels, conversation, thematic notebook, morning, holiday, a verbal journal, a group thing, making album, mind travel, contests, games, school polite, demonstration, story, simulation, quiz, excursion, exhibition of drawings, operated, fair, roll call reports, charity event, minutes with art, the hour of observation, the hour of watching, sporting events, Cossack fun, theatrical performance, puppetry, the creation of the annals cool team, fun runs, relay races, plant care and animals.

\section{References:}

1. Ben-Sasson A, Carter AS, Briggs-Gowan MJ. Sensory overresponsivity in elementary school: Prevalence and social-emotional correlates. Journal of Abnormal Child Psychology. 2009a;37:705-716.

2. Caprioglio A, Mariani L, Tettamanti L. A pilot study about emotional experiences by using CFSS-DS in young patients. European Journal of Paediatric Dentistry. 2009;10:121-124. 
3. Gustafsson A, Arnrup K, Broberg AG, Bodin L, Berggren U. Child dental fear as measured with the Dental Subscale of the Children's Fear Survey Schedule: The impact of referral status and type of informant (child versus parent) Community Dentistry and Oral Epidemiology. 2010;38:256-266.

4. Klingberg G. Dental anxiety and behavior management problems in paediatric dentistry - A review of background factors and diagnostics. European Archives of Paediatric Dentistry. 2008;9 (Suppl 1):11-15.

5. Versloot J, Veerkamp JSJ, Hoogstraten J. Dental anxiety and psychological functioning in children: Its relationship with behaviour during treatment. European Archives of Paediatric Dentistry. 2008;9(Suppl. 1):36-40.

DOI https://doi.org/10.30525/978-9934-588-81-5-2.55

\title{
ПРОБЛЕМА АЛЕРГІЧНОЇ ЗАХВОРЮВАНОСТІ У НАСЕЛЕННЯ ЕКОЛОГО-НЕБЕЗПЕЧНОГО РЕГІОНУ
}

\author{
Павленко О. I. \\ кандидат медичних наук, \\ завідувач лабораторії промислових аерозолів \\ ДУ «Украйнський науково-дослідний інститут промислової медиџини» \\ Орехова О. В. \\ кандидат медичних наук, \\ завідувач лабораторії промислового мікроклімату \\ та фізіології теплообміну \\ ДУ «Украӥнський науково-дослідний інститут промислової медицини» \\ м. Кривий Ріг, Дніпропетровська область, Украӥна \\ Вступ. Від алергічного риніту у світі страждає 4-10\% населення \\ (600 млн. осіб), у країнах Європи 3,2-19,6 \% [1, с. 117; 2, с. 556; \\ 3 , с. 7]. В Україні розповсюдженість алергічних захворювань склада- \\ ють 15-30 \%, що супроводжується втратою працездатності хворими в \\ період загострення хвороби, прогресуючим характером її перебігу та \\ формуванням бронхіальної астми [4, с. 29]. Стан техногенного забру- \\ днення атмосферного повітря впливає на агресивність пилкових алер- \\ генів, що сприяє зростанню захворюваності на поліноз у населення \\ еколого-небезпечного регіону [1, с. 116].
}

